\title{
Anticancer efficacy of biogenic silver nanoparticles in vitro
}

\author{
M. F. Kabir ${ }^{1}$ A. K. M. Atique Ullah ${ }^{2,3} \cdot$ J. Ferdousy ${ }^{4}$ M. M. Rahman ${ }^{5}$
}

Received: 29 March 2020 / Accepted: 15 May 2020 / Published online: 22 May 2020

(c) Springer Nature Switzerland AG 2020

\begin{abstract}
Silver nanoparticles (Ag-NPs) are considered as one of the most common materials that are used for various types of biomedical applications, especially as anticancer agent. In our present work, Ag-NPs were successfully synthesized by using Artocarpus heterophyllus leaf extract as a source of reducing and stabilizing agents. The structural characterization was carried out using X-ray diffraction technique and found that the synthesized Ag-NPs were face-centered cubic with an average crystallite size of $20 \mathrm{~nm}$. The elemental nature of $\mathrm{Ag}$ and other biogenic components were further evidenced from the energy dispersive $X$-ray spectroscopy analysis. The functional groups of the organic compounds that were responsible for reducing and capping agents and the presence of stabilizing agents on the surface of Ag-NPs were evidenced from the Fourier transform infrared spectroscopy analysis. The surface morphology of the biogenic Ag-NPs was monitored by using field emission scanning electron microscopy technique. The anticancer efficacy of the synthesized Ag-NPs was evaluated from the cell viability test considering two cell lines, HeLa cell which is a human carcinoma cell and Vero cell which is a normal cell. The results showed that the synthesized Ag-NPs exhibited more toxicity against carcinoma cell than normal cell indicating their potentiality as an anticancer material.
\end{abstract}

Keywords Ag NPs · Artocarpus heterophyllus · Cytotoxicity $\cdot$ HeLa cell $\cdot$ Vero cell

\section{Introduction}

Nowadays cancer is the foremost cause of humanoid death for its crucial bearing on regular cells and rapid growth of abnormal cells that grow beyond their traditional boundary which banquet over the organs [1]. Actually, cancer is a generic term that can distress several parts of human body part and substitute by the term of malignant tumors and neoplasms [2]. Moreover, cancer is a symbol of death for their uncontrolled behavior on humanoid external and internal cell line [3]. In 2018, about 9.6 million deaths was happened worldwide due to cancer, particularly lung cancer, breast cancer, liver cancer, colorectal cancer and skin cancer that are predominantly responsible for this enormous death [4].

Transformation of normal cell into tumor cell throughout a multistage process is the fundamental fact of cancer disease [5]. Including internal agent, various external agents such as physical carcinogen, chemical carcinogen and biological carcinogen are mainly liable for cancer cell materialization [6]. Early detection and appropriate diagnosis are very indispensable for selecting effective and smooth method of cancer curative treatment [7]. There are a number of renowned techniques of cancer treatment

M. F. Kabir and A. K. M. Atique Ullah have equally contributed to this article.

A. K. M. Atique Ullah, atique.chem@gmail.com; $\varangle$ M. M. Rahman, mmizan@du.ac.bd| ${ }^{1}$ Radioactivity Testing and Monitoring Laboratory, Bangladesh Atomic Energy Commission, Bagerhat 9351, Bangladesh. ${ }^{2}$ Nanoscience and Technology Research Laboratory, Chemistry Division, Atomic Energy Centre, Bangladesh Atomic Energy Commission, Dhaka 1000, Bangladesh. ${ }^{3}$ Analytical Chemistry Laboratory, Atomic Energy Centre, Bangladesh Atomic Energy Commission, Dhaka 1000, Bangladesh. ${ }^{4}$ Department of Electrical and Electronics Engineering, Green University, Dhaka 1207, Bangladesh. ${ }^{5}$ Department of Physics, University of Dhaka, Dhaka 1000, Bangladesh. 
such as surgery, radiotherapy and chemotherapy and all of them have unwelcome side effect [8]. Currently, nanomedicine is an effective and side effect free treatment way where nanoparticles play a vigorous role in whole process [9]. Ag-NPs are one of the probable applicants of cancer treatment scheme for their cell interaction and effective accomplishment on respiratory chains system [10]. This is the prominent metallic nanoparticle of DNA damaging process by forming reactive oxygen and ATP suppressing [11]. The main mechanism of DNA damaging is endocytosis which is a microbiological process and this is extremely vigorous on cancer cell comparing with normal cell [12]. Ag-NPs are also well known for their nontoxicity and ecofriendly impression [13]. There are numerous processes of synthesize of Ag-NPs such as physical, chemical and bio-synthesis, among them bio-synthesis is low cost and environmentally benign because there is no need of high price equipment and chemical reagent for this synthesize process [14].

In recent past, numerous research groups have claimed their successful synthesize of Ag-NPs from leaf extract of several trees such as Desmodium triflorum, Moringa oleifera and Cinnamomum camphora [15]. These bio-synthesized Ag-NPs are more unchanging than chemical and physical synthesized nanoparticles due to their attachment of various organic components on the surface of Ag-NPs originated from leaf extract which is actually the source of reducing and stabilizing agent [16]. This stability of Ag-NPs opens a new door in drug delivery system especially in cancer treatment mechanism [17]. Therefore, it was aimed in the present study to evaluate the anticancer efficacy of biogenic Ag-NPs which were synthesized via a facile, low-cost and environmentally friendly way. Herein, we have synthesized Ag-NPs from the reduction of $\mathrm{Ag}^{+}$using Artocarpus heterophyllus (Jackfruit) aqueous leaf extract as a reducing and stabilizing agent. Jackfruit is national fruit of Bangladesh and its leaves are important source of different organic compounds which are responsible for reduction and stabilization of Ag-NPs [18]. The anticancer efficacy of the biogenic Ag-NPs was evaluated from their in vitro cytotoxicity assessment against human carcinoma cell (HeLa cell) taking as a model carcinoma cell which was then compared against a normal cell (Vero cell).

\section{Experimental}

\subsection{Materials}

Jackfruit leaves were collected from the University of Dhaka campus, Dhaka, Bangladesh and $\mathrm{AgNO}_{3}$ was purchased from Wako pure chemical company. HeLa cell (cancer cell) and Vero cell (normal cell) were collected from the American type culture collection (Canada and USA). Dulbecco's Modified Eagles' medium was obtained from Sigma (ST. Louis, MO, USA). Fetal bovine serum was collected from Biosera (Kanas city, MO, USA). Trypan blue strain (4\%) solution was obtained from Bio-Rad (Hercules, (A, USA). All other chemicals and reagents were highly methodical grade.

\subsection{Synthesize of silver nanoparticles}

Fresh leaves of Artocarpus heterophyllus (Jackfruit) were collected locally from University of Dhaka campus and washed several times with tap water followed by de-ionized water in order to remove the dust particles and then oven dried at $80^{\circ} \mathrm{C}$ to remove the residual moisture and grinded to form powder. Then leaf extract was prepared by mixing $5 \mathrm{~g}$ of leaf powder with deionized water in a $100 \mathrm{~mL}$ of beaker. The solution was heated at $100{ }^{\circ} \mathrm{C}$ for $60 \mathrm{~min}$ and cooled at room temperature. The solution was then filtered and the filtrate termed here as leaf extract. $20 \mathrm{~mL}$ of leaf extract was added to $80 \mathrm{~mL}$ of I $\mathrm{mM} \mathrm{AgNO}_{3}$ solution dropwise. Then the solution was stirred with a magnetic string at $90^{\circ} \mathrm{C}$ and different color change was observed with naked eyes. Experiment was continued until the color of solution was changed from yellow to blackish and required time was about one and half hour. After cooling the mixture $(1 \mathrm{~h})$ the colloidal solution was centrifuged at $4000 \mathrm{rpm}$ for $10 \mathrm{~min}$. The procedure was repeated many times for producing sufficient amounts of Ag-NPs. Finally, a well-marked pellet was obtained which was washed with deionized water. Then it was dried at $70^{\circ} \mathrm{C}$ and collected for further analysis. The schematic flowchart for the synthesis of Ag-NPs is represented at Fig. 1.

\subsection{Characterization of silver nanoparticles}

The crystalline phase and crystallite size of the synthesized Ag-NPs were measured from the X-ray diffraction (XRD) analysis. The XRD patterns were recorded in the powder state of the materials using an X-ray diffractometer (PHILIPS PW 3040 X'Pert PRO, Netherlands) equipped with $\mathrm{CuK}_{\alpha}$ radiation $(\lambda=1.5418 \AA)$. The elemental analysis of the sample was obtained from energy dispersive $X$-ray (EDX) spectroscopy measurements performed by a JEOL JSM $7600 \mathrm{~F}$ instrument (Japan), using an acceleration voltage of $15 \mathrm{kV}$ and an emission current of $12 \mathrm{~mA}$. The presence of functional groups originating from the aqueous extract of Artocarpus heterophyllus which are responsible for the reduction and stabilization of Ag-NPs and their conjugation with Ag-NPs were evaluated from Fourier transform infrared (FT-IR) spectral analysis recorded on an FT-IR spectrometer (Jasco-FTIR-6300, Japan) in the wavenumber region of $4000-400 \mathrm{~cm}^{-1}$. The surface morphology 


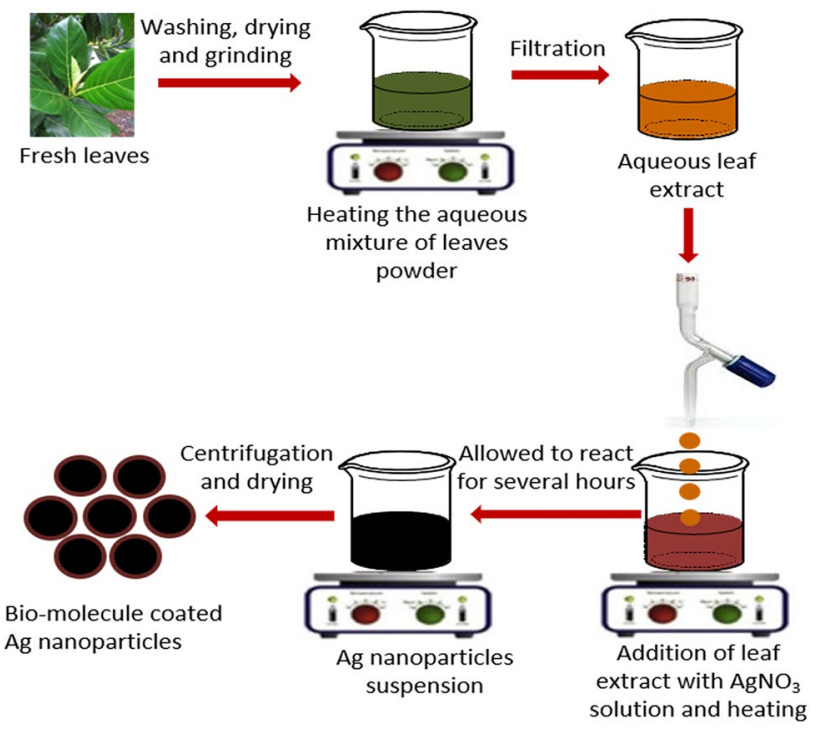

Fig. 1 Schematic diagram of preparation of Artocarpus heterophyllus leaf extract mediated Ag-NPs

was monitored by field emission scanning electron microscopy using a JEOL model JSM $7600 \mathrm{~F}$ instrument (Japan) applying an acceleration voltage of $15 \mathrm{kV}$ and an emission current of $12 \mathrm{~mA}$.

\subsection{Cytotoxicity of silver nanoparticles}

The cytotoxicity of Ag-NPs was evaluated from the cell viability experiment following Trypan blue exclusion assay [19]. The cells were cultured at $37^{\circ} \mathrm{C}$ in DMEM medium supplemented with $10 \% \mathrm{FBS}$ in a saturated incubator with $5 \% \mathrm{CO}_{2}$ in $25 \mathrm{~cm}^{2}$ culture flasks. Ag-NPs were then taken into the flasks and incubated for $48 \mathrm{~h}$. Fresh medium was added in every treatment prior to treatment. After $48 \mathrm{~h}$, the cell viability was measured using Bio-Rad automated cell counter (Herculis CA, USA). Cell viability was expressed as percentage of the total cell counts against the stained cell counts. Each experiment was performed at least three times to make sure the reproducibility of the data.

\section{Results and discussion}

\subsection{X-ray Diffraction (XRD) analysis}

The crystalline nature of biogenic Ag-NPs was confirmed using XRD technique and the corresponding Rietveld refinement XRD patterns are shown in Fig. 2.

The diffraction peaks were obtained at the $2 \theta$ values of $38.11^{\circ}, 44.33^{\circ}, 64.35^{\circ} 77.62^{\circ}$ and $82.33^{\circ}$ corresponded to the planes (111), (200), (220), (311) and (322) respectively. This suggested that the prepared Ag-NPs were

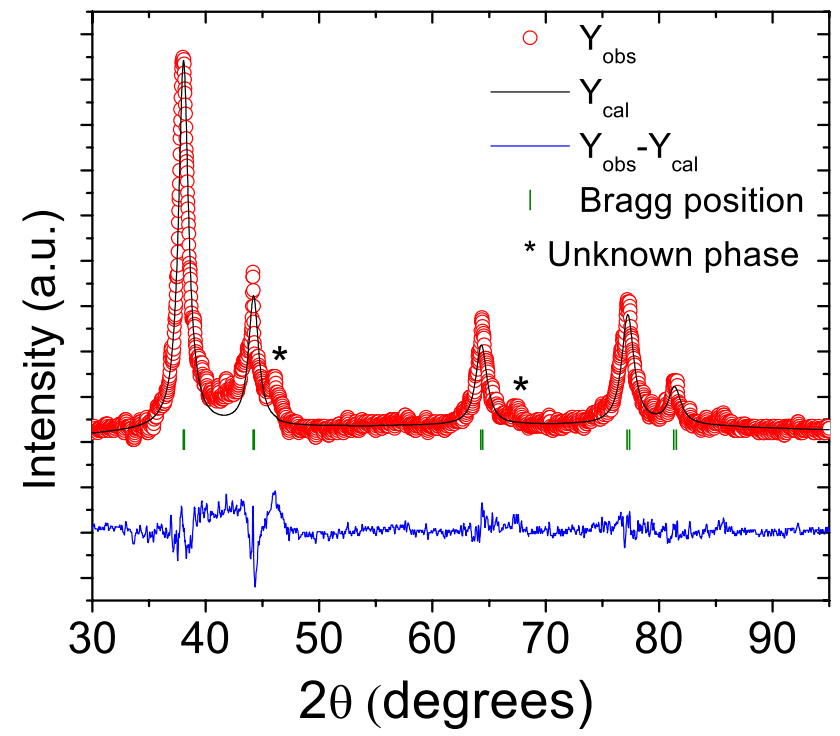

Fig. 2 XRD patterns of the green synthesized Ag-NPs

face-centered cubic crystal lattice [20]. In addition, the unsigned peaks (marked as *) may be associated with the bio-molecules which were originated from the jackfruit leaf extract and acted as capping agents that promote the stability of the Ag-NPs. The average crystallite size of the prepared samples was determined from the strongest peak of XRD profile using Scherrer's formula [21]. The calculated crystallite size was found about $20 \mathrm{~nm}$. The lattice constant calculated from XRD pattern has been found to be $a=0.4096 \mathrm{~nm}$, which is consistent with the standard value $\mathrm{a}=0.4086 \mathrm{~nm}$. The obtained data showed good agreement with the database of the International Centre for Diffraction Data (ICDD) card no. 87-0597.

\subsection{Energy Dispersive X-ray (EDX) Spectral analysis}

Elemental analysis of the synthesized Ag-NPs was performed using EDX spectra analysis and is shown in Fig. 3. The EDX profile showed strong signals for silver atoms. The strong signal peak at $3 \mathrm{keV}$ in the EDX spectrum was typical of the absorption of silver [22]. Interestingly, some other elements such as $\mathrm{C}, \mathrm{Cl}$ and $\mathrm{O}$ were also detected. $\mathrm{C}$ and $\mathrm{O}$ and are very likely associated with the organic compounds from the extract adsorbed on the surface of AgNPs which play a crucial role in the reduction and stability of Ag NPs. Cl may also come from the leaf extract solution.

\subsection{Fourier Transform Infrared (FT-IR) spectra analysis}

The FT-IR spectra of the dried sample of Artocarpus heterophyllus (jackfruit) leaves powder and synthesized 


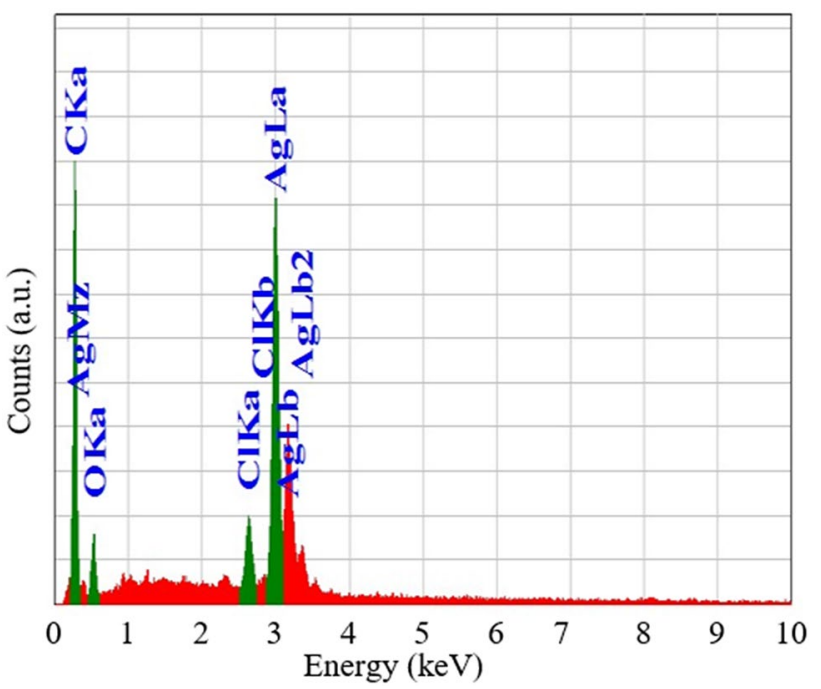

Fig. 3 EDX image showing the presence of Ag-NPs and bioorganic components of Artocarpus heterophyllus leaf extract

Ag-NPs were recorded by an FT-IR spectrophotometer in the region of $4000-400 \mathrm{~cm}^{-1}$ and shown in Fig. $4 \mathrm{a}, \mathrm{b}$ respectively. FT-IR measurements were carried out in order to identify the possible bio-molecules responsible for the reduction of the $\mathrm{Ag}^{+}$ions and capping agents that stabilize the Ag-NPs. Figure 4a represents the FT-IR spectrum of the Artocarpus heterophyllus leaf (jackfruit leaf) powder and the peaks were obtained at $478,659,1068,1242,1321$, $1379,1433,1627,2856,2924,3435,3693$ and $3768 \mathrm{~cm}^{-1}$. The corresponding organic functional groups for peak values were might be $478 \mathrm{~cm}^{-1}$ for $\mathrm{C}-\mathrm{X}$ (alkyl halide), $659 \mathrm{~cm}^{-1}$ for C-Cl (alkyl chloride), $1068 \mathrm{~cm}^{-1}$ for O-H (alcohol) or C-F (alkyl fluoride), $1242 \mathrm{~cm}^{-1}, 1321 \mathrm{~cm}^{-1}$ and $1379 \mathrm{~cm}^{-1}$ for different types of amine group $(\mathrm{N}-\mathrm{H}), 1433 \mathrm{~cm}^{-1}$ for $-\mathrm{C}-\mathrm{H}$ (alkane) or $\mathrm{C}=\mathrm{C}$ (aromatic), $1627 \mathrm{~cm}^{-1}$ for $\mathrm{C}=\mathrm{C}$ (alkene) or $\mathrm{C}=\mathrm{O}$ (carbonyl), $2856 \mathrm{~cm}^{-1}$ and $2924 \mathrm{~cm}^{-1}$ for alkanes, $3435 \mathrm{~cm}^{-1}$ for $\mathrm{N}-\mathrm{H}$ (amine), $3693 \mathrm{~cm}^{-1}$ and $3768 \mathrm{~cm}^{-1}$ for $\mathrm{O}-\mathrm{H}$ (alcohol) [23-25]. It is possible that the terpenoids also contributed to the reduction of the silver ions and, in the process, are oxidized to carbonyl groups that thus resulted in a band at $1627 \mathrm{~cm}^{-1}$. On formation of Ag-NPs, the peak corresponding to the amine band at $1242 \mathrm{~cm}^{-1}$ has broadened and indicates capping of the Ag-NPs by the protein [26]. It is well-known that proteins can bind to Ag-NPs through free amine group residues in the proteins [27]. A similar mechanism could be operating in the present case where proteins extracted from the $P$. graveolens leaf cap the Ag-NPs, thereby stabilizing them [28]. It is evidenced that plants secrete a number of secondary metabolites covering a range of organic structures.

Figure $4 \mathrm{~b}$ depicted the leaf extract mediated Ag-NPs and the obtained peaks are corresponded to $503 \mathrm{~cm}^{-1}$ for (alkyl halide), $1103 \mathrm{~cm}^{-1}$ for (alcohol) or C-N (amine),
$1382 \mathrm{~cm}^{-1}$ for $\mathrm{C}-\mathrm{H}$ (alkane) or $\mathrm{C}-\mathrm{F}$ (alkyl halide), $1622 \mathrm{~cm}^{-1}$ for $\mathrm{C}=\mathrm{C}$ (alkene) and $3466 \mathrm{~cm}^{-1}$ for $\mathrm{O}-\mathrm{H}$ (alcohol) or $\mathrm{N}-\mathrm{H}$ (amine) $[26,27]$. It is certainly possible that a number of other bio-organic compounds can exist in solution and participate in the reduction of silver ions and in the stabilization of the nanoparticles thus formed by surface capping. Efforts are currently underway to isolate the different bio-organic fractions in the jackfruit leaf broth and test them individually for silver ion reduction and binding with the nanoparticles.

\subsection{Field emission scanning electron microscopy (FESEM) analysis}

The surface morphology of the synthesized Ag-NPs was monitored using field emission scanning electron microscopy (FESEM) technique and shown in Fig. 5. The FESEM image of Ag-NPs demonstrated that the synthesized AgNPs are almost uniformly distributed with some agglomeration. An intense look depicted that most of the Ag-NPs below the size of $50 \mathrm{~nm}$. However, some large particles are viewed probably resulted from the agglomeration of small ones. The large particle may be removed through heat treatment. The lower agglomeration is might be due to the presence of capping agents present on the surface of Ag-NPs, which is also evidenced from the EDX and FT-IR analyses.

\subsection{Cytotoxicity of synthesized silver nanoparticles}

The cytotoxicity of Ag-NPs was assessed from the cell viability test taking two cell lines taking HeLa cell, a human carcinoma cell and Vero cell, normal cell as shown in Figs. 6 and 7. The synthesized Ag-NPs were exposed to the cell lines at different concentrations. The Ag-NPs were found to be active against two different cell lines at different concentrations. From the cell viability experiment it is found that the synthesized Ag-NPs are found to be non-toxic up to $10 \mathrm{mg} / \mathrm{L}$ as shown in Fig. 6 .

The cell viability experiment also showed that the cell viability was found to be decreased after the exposure of $20 \mathrm{mg} / \mathrm{L}$ for HeLa cell and then decreased following the concentration dependent manner. In case of Vero cell, the cell viability was found to be decreased at an exposure of $50 \mathrm{mg} / \mathrm{L}$ and then decreased with the increase in concentration as shown in Fig. 7. The cytotoxicity test proves that the biogenic Ag-NPs was found to be effective against cancer cell than normal cell indicating the safe use of Ag$\mathrm{NPs}$ up to $10 \mathrm{mg} / \mathrm{L}$. It is also evidenced that Ag-NPs can damage the cancer cell at a concentration of $20 \mathrm{mg} / \mathrm{L}$ at which it cannot damage the normal cell indicating its application as anticancer agent. The cytotoxicity results are summarized in Table 1. 
Fig. 4 FT-IR spectra of Artocarpus heterophyllus (AH) leaf powder and $\mathrm{AH}$ leaf extract mediated synthesized Ag-NPs

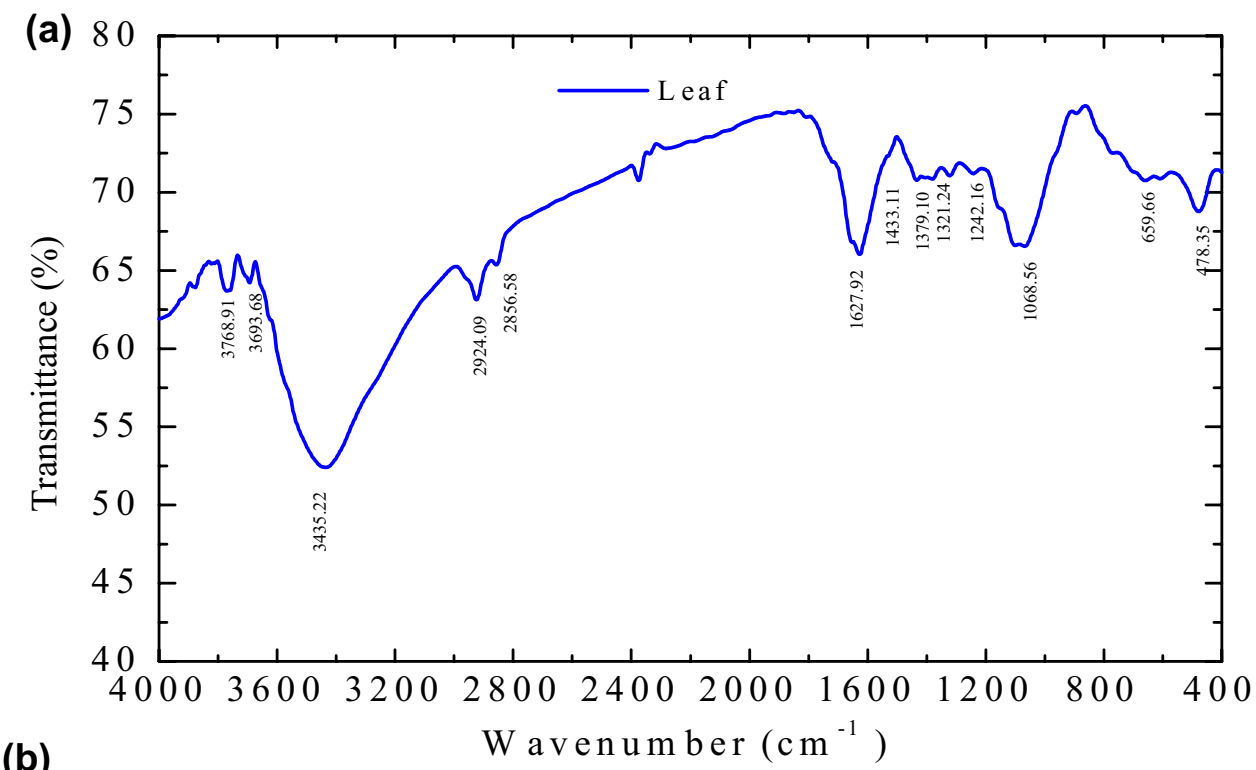

(b)

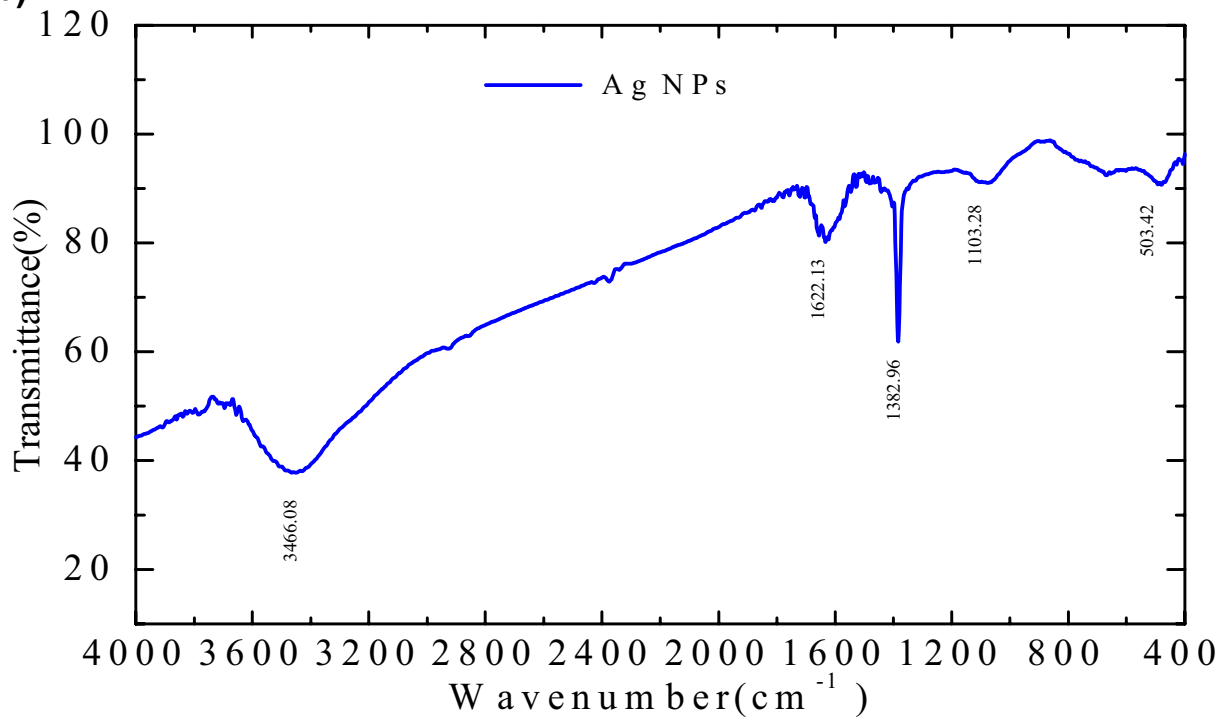

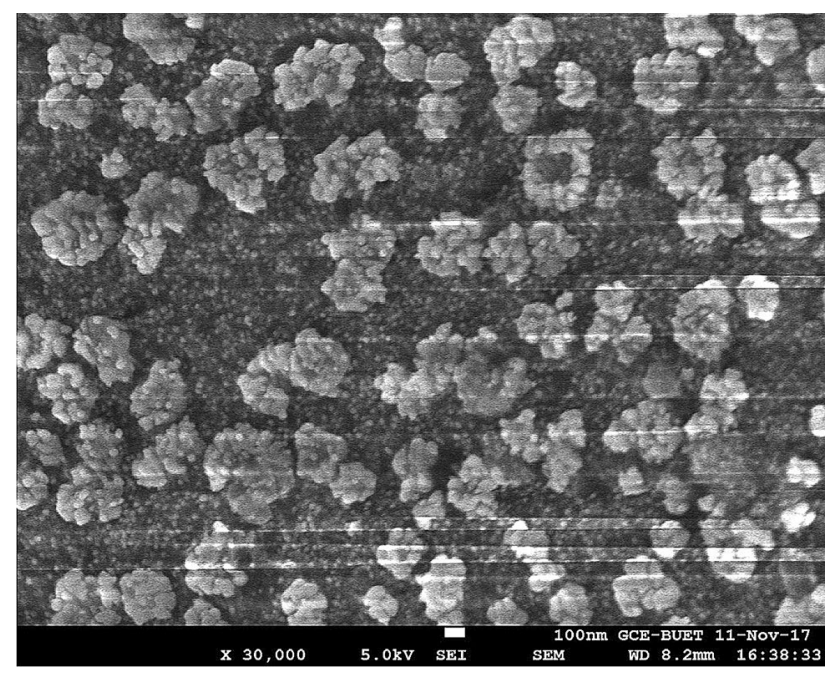

Fig. 5 FESEM micrograph of the biosynthesized Ag-NPs
The mechanism of cytotoxicity of Ag-NPs is still unclear though it varies from cell to cell. Moreover, the cytotoxic and genotoxic effect of Ag-NPs is dependent on their concentration, size, exposure time and environmental factors. In addition, nanosilver surface-coating agents, such as citric acid, amino acids, acetyl trimethyl ammonium bromide and sodium dodecyl sulfate are noncovalently attached to nanosilver particles and can be released into the environmental and biological media with or without interaction with biological macromolecules, and inorganic and organic ions cause the NPs to be unstable in media. Additionally, particle aggregation, surface oxidation to form silver oxide and oxidation of silver oxide release both $\mathrm{Ag}^{+}$and $\mathrm{Ag}^{0}$ into the media, which eventually results in accumulation of ionic silver in the environmental media, biological media and inside the cell through diffusion or endocytosis, causing mitochondrial dysfunction. Ag-NPs 

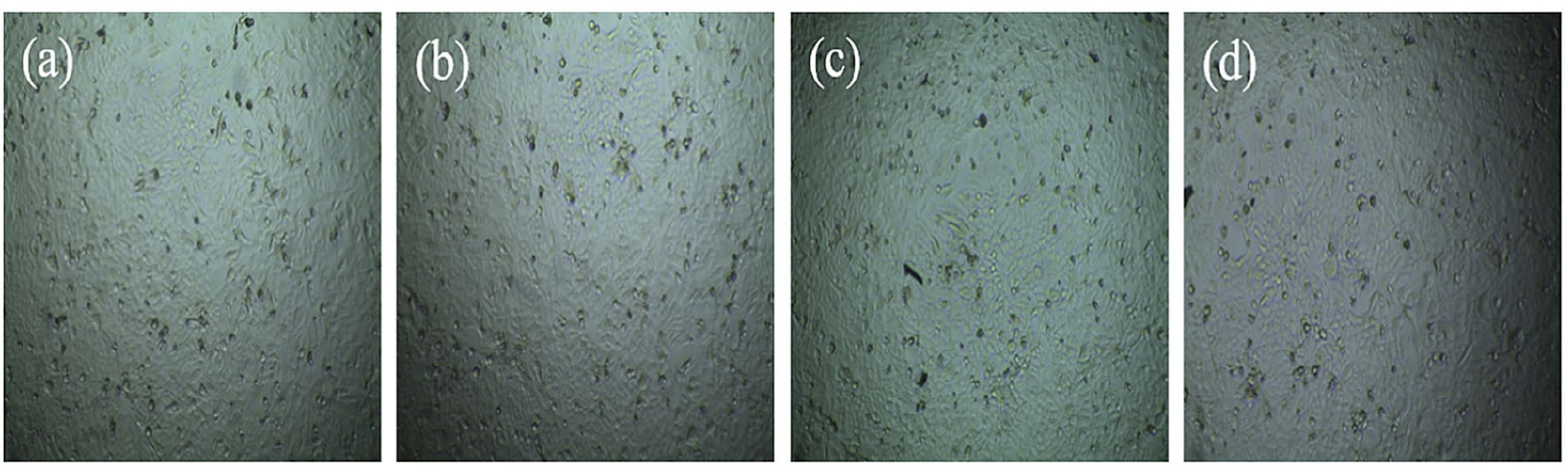

0
$\stackrel{0}{=}$
0
0
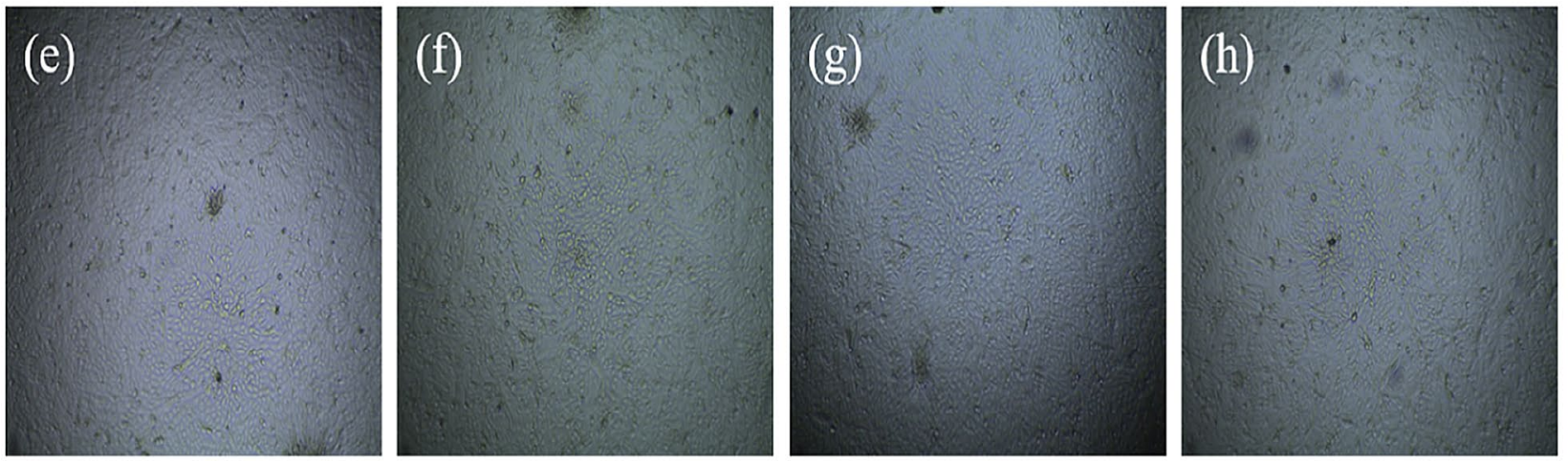

Fig. 6 Phase contrast microscopic images of Ag-NPs induced cytomorphological changes and growth inhibition of HeLa and Vero cell lines with control and at different concentrations. a Control, b $2 \mathrm{mg} / \mathrm{L}, \mathbf{c} 5 \mathrm{mg} / \mathrm{L}, \mathbf{d} 10 \mathrm{mg} / \mathrm{L}$ and e control, f $2 \mathrm{mg} / \mathrm{L}, \mathbf{g} 5 \mathrm{mg} / \mathrm{L}, \mathbf{h} 10 \mathrm{mg} / \mathrm{L}$
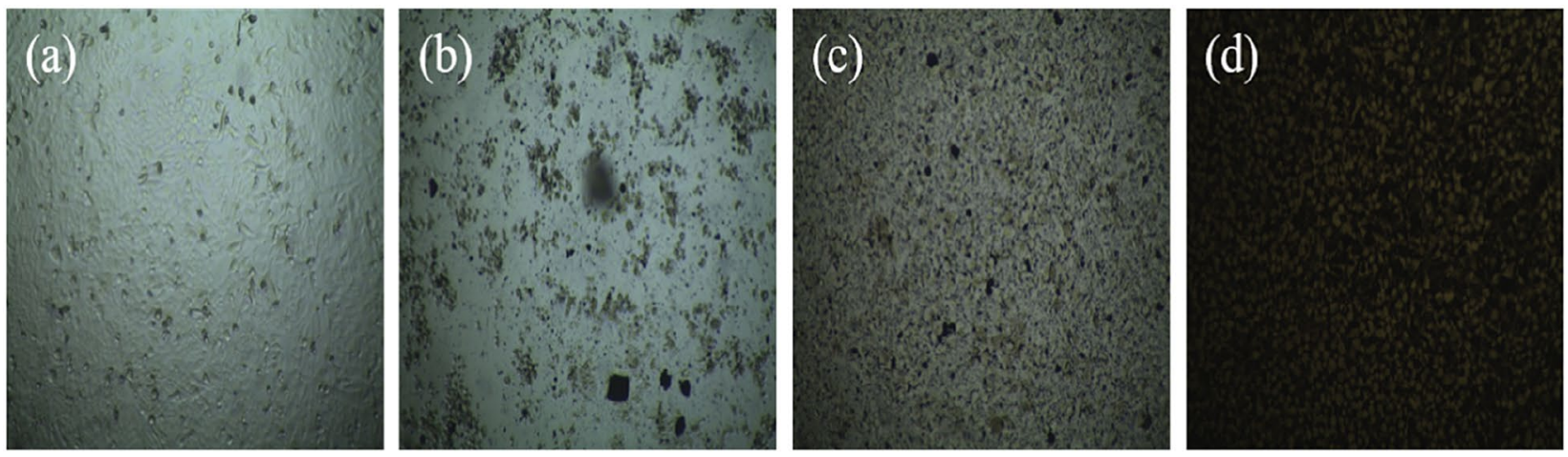

0
0
0
0
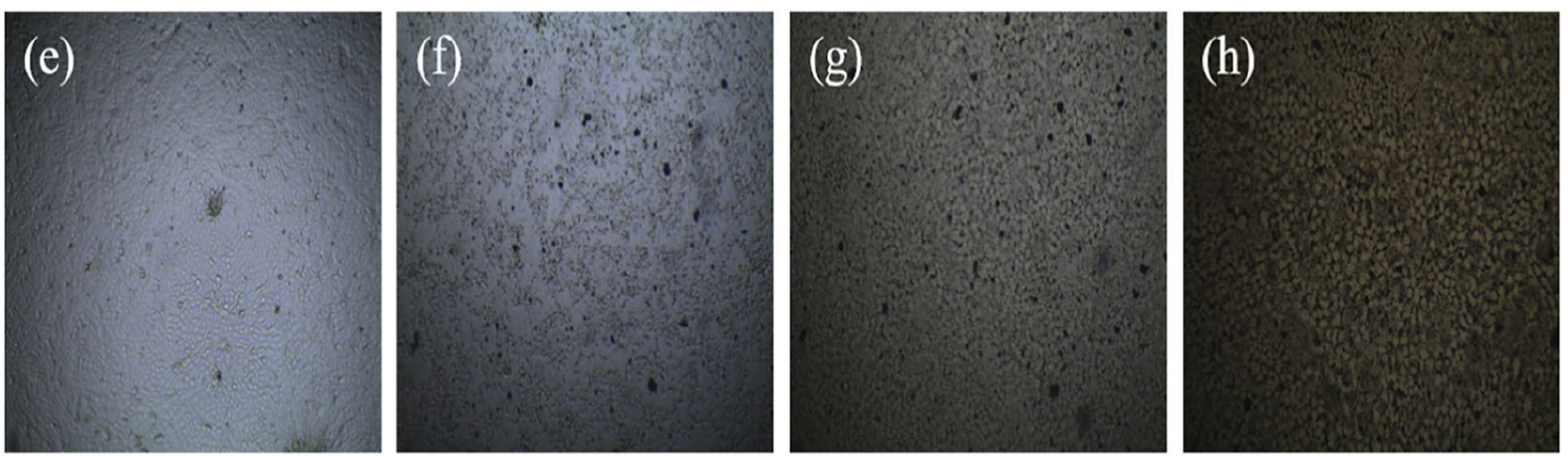

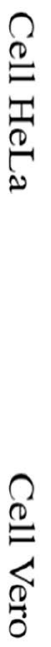

Fig. 7 Phase contrast microscopic images of Ag-NPs induced cytomorphological changes and growth inhibition of HeLa and Vero cell line with control and at different concentrations. a Control, b $20 \mathrm{mg} / \mathrm{L}, \mathbf{c} 50 \mathrm{mg} / \mathrm{L}, \mathbf{d ~} 100 \mathrm{mg} / \mathrm{L}$ and e control, f $20 \mathrm{mg} / \mathrm{L}, \mathbf{g ~} 50 \mathrm{mg} / \mathrm{L}$, h $100 \mathrm{mg} / \mathrm{L}$

\section{SN Applied Sciences}

A SPRINGER NATURE journal 
Table 1 Cell viability after the exposure of silver nanoparticles

\begin{tabular}{llll}
\hline Sl. no. & $\begin{array}{l}\text { Concentration of } \\
\text { Ag-NPs }\end{array}$ & \multicolumn{2}{l}{ Cell visibility } \\
\cline { 3 - 4 } & Hela (\%) & Vero (\%) \\
\hline 1 & Control & $>95$ & $>95$ \\
2 & $2 \mathrm{mg} / \mathrm{L}$ & $>95$ & $>95$ \\
3 & $5 \mathrm{mg} / \mathrm{L}$ & $>95$ & $>95$ \\
4 & $10 \mathrm{mg} / \mathrm{L}$ & $>95$ & $>95$ \\
5 & $20 \mathrm{mg} / \mathrm{L}$ & $>83$ & $>95$ \\
6 & $50 \mathrm{mg} / \mathrm{L}$ & $>67$ & $>85$ \\
7 & $100 \mathrm{mg} / \mathrm{L}$ & $>35$ & $>68$ \\
\hline
\end{tabular}

then interact with cell membrane proteins and activate signaling pathways to generate reactive oxygen species (ROS), leading to damage of proteins and nucleic acids caused by the strong affinity of silver for sulfur and finally causing apoptosis and inhibition of cell proliferation [29].

\section{Conclusion}

A method for Ag-NPs synthesizes by the reduction of silver ions using Artocarpus heterophyllus aqueous leaf extract as a reducing and capping agent has been developed. The experimental techniques, XRD, EDX, FT-IR and FESEM analyses demonstrated the successful synthesis of biogenic Ag-NPs. It was established by the in vitro test that the synthesized biogenic Ag-NPs exhibited more toxicity towards human carcinoma cell (HeLa cell) compared to normal cells (Vero cells). Thus, it can be concluded that the biogenic Ag-NPs indicate their potential activity as anticancer material.

\section{Compliance with ethical standards}

Conflict of interest The authors declare that they do not have any conflict of interest to declare.

\section{References}

1. Odes EJ, Randolph-Quinney PS, Steyn M, Throckmorton Z, Smilg JS, Zipfel B, Augustine TN, Beer FD, Hoffman JW, Franklin RD, Berger LR, Afr S (2016) Earliest hominin cancer: 1.7-millionyear-old osteosarcoma from Swartkrans Cave, South Africa. J Sci 112:1-5

2. Esserman LJ, Thompson IM, Reid B, Nelson P, Ransohoff DF, Welch HG, Hwang S, Berry DA, Kinzler KW, Black WC, Bissell M (2014) Addressing overdiagnosis and overtreatment in cancer: a prescription for change. Lancet Oncol 15:234-242

3. Stratmann HG (2016) Hurting and healing characters. In: Using medicine in science fiction. Springer, Cham, pp 41-87
4. Feng RM, Zong YN, Cao SM, Xu RH (2019) Current cancer situation in China: good or bad news from the 2018 Global Cancer Statistics? Cancer Commun 39:22-30

5. Peto R (2016) Epidemiology, multistage models, and short-term mutagenicity tests. Int J Epidemiol 45:621-637

6. Kadhim KJ (2016) Theories of tumor. Tikrit Med J 21:322-326

7. Wu X, Chen J, Wu M, Zhao JX (2015) Aptamers: active targeting ligands for cancer diagnosis and therapy. Theranostics 5:322-344

8. Almeida CED, Alves LV, Rocha HF, Cabral-Neto JB, Missailidis $S$ (2017) Aptamer delivery of siRNA, radiopharmaceutics and chemotherapy agents in cancer. Int J Pharm 525:334-342

9. Prasad M, Lambe UP, Brar B, Shah I, Manimegalai J, Ranjan K, Rao R, Kumar S, Mahant S, Khurana SK, Iqbal HM (2018) Nanotherapeutics: an insight into healthcare and multi-dimensional applications in medical sector of the modern world. Biomed Pharmacother 97:1521-1537

10. Khan Y, Numan M, Ali M, Khali AT, Ali T, Abbas N, Shinwari ZK (2017) Bio-synthesized silver nanoparticles using different plant extracts as anti-cancer agent. J Nanomed Biother Discov 7:2-7

11. Ma W, Jing L, Valladares A, Mehta SL, Wang Z, Li PA, Bang JJ (2015) Silver nanoparticle exposure induced mitochondrial stress, caspase- 3 activation and cell death: amelioration by sodium selenite. Int J Biol Sci 11:860-867

12. Ishida $T$ (2017) Anticancer activities of silver ions in cancer and tumor cells and DNA damages by $\mathrm{Ag}^{+}$-DNA base-pairs reactions. MOJ Tumor Res 1:3-9

13. Rafique M, Sadaf I, Rafique MS, Tahir MB (2017) A review on green synthesis of silver nanoparticles and their applications. Artif Cells Nanomed Biotechnol 45:1272-1291

14. Akter M, Ullah AKMA, Rahaman MS, Rahman MM, Sikder MT, Hosokawa T, Saito T, Kurasaki M (2020) Stability enhancement of silver nanoparticles through surface encapsulation via a facile green synthesis approach and toxicity reduction. J Inorg Organomet Polym 30:1956-1965

15. Sulaiman GM, Mohammed WH, Marzoog TR, AIAmiery AAA, Kadhum AAH, Mohamad AB (2013) Green synthesis, antimicrobial and cytotoxic effects of silver nanoparticles using Eucalyptus chapmaniana leaves extract. Asian Pac J Trop Biomed 3:58-63

16. Uddin AKMR, Siddique MAB, Rahman F, Ullah AKMA, Khan $R$ (2020) Cocos nucifera leaf extract mediated green synthesis of silver nanoparticles for enhanced antibacterial activity. J Inorg Organomet Polym. https://doi.org/10.1007/s10904-020-01506 $-9$

17. Ovais M, Khalil AT, Raza A, Khan MA, Ahmad I, Islam NU, Saravanan M, Ubaid MF, Ali M, Shinwari ZK (2016) Biosynthesis of silver nanoparticles from Hyphaene thebaica fruits and their in vitro pharmacognostic potential. Nanomedicine 12:3157-3177

18. Basavegowda N, Kumar GD, Tyliszczak B, Wzorek Z, SobczakKupiec A (2015) One-step synthesis of highly-biocompatible spherical gold nanoparticles using Artocarpus heterophyllus Lam. (jackfruit) fruit extract and its effect on pathogens. Ann Agric Environ Med 22:84-89

19. Akter M, Rahman MM, Ullah AKMA, Sikder MT, Hosokawa T, Saito T, Kuasaki M (2018) Brassica rapa var. japonica leaf extract mediated green synthesis of crystalline silver nanoparticles and evaluation of their stability, cytotoxicity and antibacterial activity. J Inorg Organomet Polym 28:1483-1493

20. Jyoti K, Baunthiyal M, Singh A (2016) Green synthesis of silver nanoparticles using Aganonerion polymorphum leaves extract and evaluation of their antibacterial and catalytic activity. J Radiat Res Appl Sci 9:217-227

21. Ullah AKMA, Kibria AKMF, Akter M, Khan MNI, Tareq ARM, Firoz $\mathrm{SH}$ (2017) Oxidative degradation of methylene blue using $\mathrm{Mn}_{3} \mathrm{O}_{4}$ nanoparticles. Water Conserv Sci Eng 1:249-256 
22. Ullah AKMA, Kabir MF, Akter M, Tamanna AN, Hossain A, Tareq ARM, Khan MNI, Kibria AKMF, Kurasaki M, Rahman MM (2018) Green synthesis of bio-molecule encapsulated magnetic silver nanoparticles and their antibacterial activity. RSC Adv 8:37176-37183

23. Ullah AKMA, Tamanna AN, Hossain A, Akter M, Kabir MF, Tareq ARM, Kibria AKMF, Kurasaki M, Rahman MM, Khan MNI (2019) In vitro cytotoxicity and antibiotic application of green route surface modified ferromagnetic $\mathrm{TiO}_{2}$ nanoparticles. RSC Adv 9:13254-13262

24. Chandhru M, Logesh R, Rani SK, Ahmed N, Vasimalai N (2019) One-pot green route synthesis of silver nanoparticles from jack fruit seeds and their antibacterial activities with Escherichia coli and Salmonella bacteria. Biocatal Agric Biotechnol 20:101241

25. Ullah AKMA, Haque MM, Akter M, Hossain A, Tamanna AN, Hosen MM, Kibria AKMF, Khan MNI, Khan MKA (2020) Green synthesis of Bryophyllum pinnatum aqueous leaf extract mediated biomolecule capped dilute ferromagnetic a- $\mathrm{MnO}_{2}$ nanoparticles. Mater Res Express 7:015088

26. Ojha AK, Bulasara VK (2015) Adsorption characteristics of jackfruit leaf powder for the removal of Amido black 10B dye. Environ Prog Sustain Energy 34:461-470
27. Rahim KA, Mahmoud SY, Ali AM, Almaary KS, Mustafa AEZM, Husseiny SM (2017) Extracellular biosynthesis of silver nanoparticles using Rhizopus stolonifer (mould). Saudi J Biol Sci 24:208-216

28. Ovais M, Khalil AT, Islam NU, Ahmad I, Ayaz M, Saravanan M, Shinwari ZK, Mukherjee S (2018) Role of plant phytochemicals and microbial enzymes in biosynthesis of metallic nanoparticles. Appl Microbiol Biotechnol 102:6799-6814

29. Akter M, Sikder MT, Rahman MM, Ullah AKMA, Hossain KFB, Kurasaki M (2018) A systematic review on silver nanoparticlesinduced cytotoxicity: physicochemical properties and perspectives. J Adv Res 9:1-16

Publisher's Note Springer Nature remains neutral with regard to jurisdictional claims in published maps and institutional affiliations. 